\title{
Formation of $\mathrm{NO}$ from N2/O2 mixtures in a flow reactor: Toward an accurate prediction of thermal NO
}

\author{
Abian, Maria; Alzueta, Maria U.; Glarborg, Peter
}

Published in:

International Journal of Chemical Kinetics

Link to article, DOI:

10.1002/kin.20929

Publication date:

2015

Document Version

Peer reviewed version

Link back to DTU Orbit

Citation (APA):

Abian, M., Alzueta, M. U., \& Glarborg, P. (2015). Formation of $N O$ from $N_{2} / O_{2}$ mixtures in a flow reactor: Toward an accurate prediction of thermal NO. International Journal of Chemical Kinetics, 47(8), 518-532.

https://doi.org/10.1002/kin.20929

\section{General rights}

Copyright and moral rights for the publications made accessible in the public portal are retained by the authors and/or other copyright owners and it is a condition of accessing publications that users recognise and abide by the legal requirements associated with these rights.

- Users may download and print one copy of any publication from the public portal for the purpose of private study or research.

- You may not further distribute the material or use it for any profit-making activity or commercial gain

- You may freely distribute the URL identifying the publication in the public portal

If you believe that this document breaches copyright please contact us providing details, and we will remove access to the work immediately and investigate your claim. 


\title{
Formation of $\mathrm{NO}$ from $\mathrm{N}_{2} / \mathrm{O}_{2}$ Mixtures in a Flow Reactor: Towards an Accurate Prediction of Thermal NO.
}

\author{
Maria Abian ${ }^{1}$, Maria U. Alzueta ${ }^{1}$, and Peter Glarborg ${ }^{2}$ \\ 1: Aragón Institute of Engineering Research (I3A), University of Zaragoza, \\ Campus Rio Ebro, 50018 Zaragoza, Spain \\ 2: DTU Chemical Engineering, Technical University of Denmark, 2800 Lyngby, \\ Denmark
}

\begin{abstract}
We have conducted flow reactor experiments for NO formation from $\mathrm{N}_{2} / \mathrm{O}_{2}$ mixtures at high temperatures and atmospheric pressure, controlling accurately temperature and reaction time. Under these conditions, atomic oxygen equilibrates rapidly with $\mathrm{O}_{2}$. The experimental results were interpreted by a detailed chemical model to determine the rate constant for the reaction $\mathrm{N}_{2}+\mathrm{O} \rightleftharpoons \mathrm{NO}+\mathrm{N}(\mathrm{R} 1)$. We obtain $\mathrm{k}_{1}=1.4 \cdot 10^{14} \exp (-38300 / \mathrm{T}) \mathrm{cm}^{3} \mathrm{~mol}^{-1} \mathrm{~s}^{-1}$ at $1700-1800 \mathrm{~K}$, with an error limit of $\pm 30 \%$. This value is $25 \%$ below the recommendation of Baulch et al. for $\mathrm{k}_{1}$, while it corresponds to a value $\mathrm{k}_{1 \mathrm{~b}}$ of the reverse reaction $25 \%$ above the Baulch et al. evaluation. Combination of our results with literature values leads to a recommended rate constant for $\mathrm{k}_{1 \mathrm{~b}}$ of $9.4 \times 10^{12} \mathrm{~T}^{0.14} \mathrm{~cm}^{3} \mathrm{~mol}^{-1} \mathrm{~s}^{-1}$ over $250-3000 \mathrm{~K}$. This value, which reconciles the differences between the forward and reverse rate constant, is recommended for use in kinetic modeling.
\end{abstract}




\section{Introduction}

The emission of nitrogen oxides ( $\mathrm{NO}$ and $\mathrm{NO}_{2}$ ) remains one of the major environmental concerns when designing and optimizing combustion systems. A significant amount of work has been devoted to improve the understanding of $\mathrm{NO}_{\mathrm{x}}$ formation mechanisms in combustion and to develop control strategies to reduce emissions [1-3]. Future legislation on pollutant emissions from combustion of natural gas is likely to be more stringent, as this fuel will account for an increasing share of power and heat generation. Since natural gas contains no or negligible amounts of fuel-bound nitrogen, formation of $\mathrm{NO}$ arises from fixation of $\mathrm{N}_{2}$ in the combustion air. Thermal $\mathrm{NO}$ will also be formed when burning other fuels in an air atmosphere; most pronounced for fuels like oil or woody biomass with a low nitrogen content. Homogeneous mechanisms for fixation of $\mathrm{N}_{2}$ involve the attack of reactive radicals $(\mathrm{O}$, $\left.\mathrm{CH}_{\mathrm{i}}, \mathrm{H}\right)$ on the triple bond in molecular nitrogen [1-4]. These reactions form either $\mathrm{NO}$ or a reactive nitrogen intermediate $\left(\mathrm{N}_{2} \mathrm{O}\right.$, cyanides, $\left.\mathrm{NNH}\right)$ that may subsequently be oxidized to NO. The thermal NO or Zeldovich mechanism [5] remains the most important source of NO in gas combustion. Formation of prompt NO may also be significant in practical gaseous flames, while formation of $\mathrm{NO}$ through $\mathrm{N}_{2} \mathrm{O}$ or through $\mathrm{NNH}$ for most applications is believed to be of minor importance.

The mechanism of thermal NO formation is well established. The initiating step is attack of an oxygen atom on the triple bond in $\mathrm{N}_{2}$,

$$
\mathrm{O}+\mathrm{N}_{2} \rightleftharpoons \mathrm{NO}+\mathrm{N}
$$

This reaction has a high activation energy and it is the rate limiting step in thermal NO formation. Once formed the nitrogen atom is rapidly oxidized to $\mathrm{NO}$ by reaction with $\mathrm{OH}$ or $\mathrm{O}_{2}$,

$$
\begin{aligned}
& \mathrm{N}+\mathrm{OH} \rightleftharpoons \mathrm{NO}+\mathrm{H} \\
& \mathrm{N}+\mathrm{O}_{2} \rightleftharpoons \mathrm{NO}+\mathrm{O}
\end{aligned}
$$

The rate constant for the rate limiting step (R1) in thermal NO formation has been measured directly in shock tube studies $[6,7]$ and inferred from a number of flame studies [8-15]. In addition, the reverse reaction,

$$
\mathrm{N}+\mathrm{NO} \rightleftharpoons \mathrm{O}+\mathrm{N}_{2}
$$


has been characterized experimentally over a wide range of temperature and pressure [16-34]. Despite the extensive measurements, the values of $\mathrm{k}_{1}$ and $\mathrm{k}_{1 \mathrm{~b}}$, respectively, are not known with an accuracy better than a factor of two, according to the evaluation of Baulch et al. [35]. Furthermore, at high temperatures the Baulch recommendation for $\mathrm{k}_{1}$ is $50-70 \%$ larger than the value derived from their recommendation for $\mathrm{k}_{1 \mathrm{~b}}$ and the equilibrium constant. This way, a modeling prediction of thermal NO formation depends significantly on whether the key reaction is listed in the mechanism in the forward or reverse direction.

The objective of the present work is to obtain an accurate high-temperature measurement of the rate constant for the $\mathrm{O}+\mathrm{N}_{2}$ reaction (R1), and to reconcile the inconsistency between reported values of $k_{1}$ and $k_{1 b}$. We conduct flow reactor experiments for $\mathrm{N}_{2} / \mathrm{O}_{2}$ mixtures in the temperature range 1700$1800 \mathrm{~K}$ and at atmospheric pressure, monitoring the NO formation. The experimental results, obtained at conditions with accurately controlled temperature and reaction times and interpreted by a detailed chemical model, are used to derive values for $\mathrm{k}_{1}$ in this temperature range. Based on the present data, as well as literature data for the forward and reverse reaction, we propose a rate constant for $\mathrm{N}+\mathrm{NO} \longrightarrow \mathrm{N}_{2}+\mathrm{O}(\mathrm{R} 1 \mathrm{~b})$ for the temperature range 250-3000 K. Predictions with an updated reaction mechanism for thermal NO formation are then compared to experimental data reported in the literature for thermal NO formation in flow reactors, jet-stirred reactors, shock tubes, and laminar premixed flames.

\section{Experimental Setup and Procedure}

The experiments were carried out in an experimental setup used with success in previous work (see for instance $[36,37]$ ), addressing homogeneous gasphase reactions at temperatures up to $1800 \mathrm{~K}$. The reaction system included a non-porous alumina tube reactor with $40 \mathrm{~mm}$ inside diameter and $800 \mathrm{~mm}$ in length. It has been reported that nitric oxide may decompose on alumina surfaces [38]. However, the alumina used in the present work was sintered and had a very low reactivity. Furthermore, the reactor used had a low S/V ratio of 0.5 . 
The reactor was placed in a one-zone electrically heated oven which allowed temperatures up to $1800 \mathrm{~K}$. Figure 1 shows a scheme of the reactor and the profiles achieved for the different reaction temperatures. The temperature profile in the reactor was measured with a type-S platinum ceramic-covered thermocouple. The uncertainty in temperature measurement with the type $\mathrm{S}$ thermocouple was estimated to be $1.6 \mathrm{~K}$ at $1723 \mathrm{~K}$. The effect of radiation on temperature measurements were found to be below $13 \mathrm{~K}$ at $1800 \mathrm{~K}$ [37]. Therefore, the overall uncertainty in the temperature measurements is lower than $15 \mathrm{~K}$ in the temperature range considered in this study. Due to the high sensitivity to temperature of the rate limiting reaction $(R 1)$, this uncertainty corresponds to an estimated uncertainty in the NO formation of $\pm 30 \%$ in the 1700-1800 K temperature range.

Gases $\left(\mathrm{O}_{2}\right.$ and $\left.\mathrm{N}_{2}\right)$ were led to the reactor at room temperature through mass flow controllers from cylinders. The Brooks mass flow controllers present a full scale error of $1.5 \%$. However, each flow rate was manually checked with a flow meter, reducing the uncertainty of the flows to negligible values. The gas cylinders contained high purity gases with a relative uncertainty of $2 \%$ determined for a confidence interval of $95 \%$. Water vapor was fed by saturating a nitrogen stream through a bubbling water system at room temperature. Presence of $\mathrm{H}_{2} \mathrm{O}$ facilitates a rapid partial equilibrium between $\mathrm{O}$ and $\mathrm{O}_{2}$. The gases were mixed just prior the reactor inlet. At the outlet of the reaction zone, the product gas was cooled by means of external refrigeration with air. The NO concentration was measured by means of a continuous infrared (IR) analyzer module Uras 14 . The uncertainty in the NO measurement reported by this analyzer was $\leq 0.5 \%$ of span.

The experiments were carried out under well-controlled conditions at atmospheric pressure and temperatures of $1700-1800 \mathrm{~K}$. The total flow rate was $1000 \mathrm{~mL}(\mathrm{STP}) / \mathrm{min}$. Initial mixtures of $0.45,1.8,8.0$, and $20.9 \% \mathrm{O}_{2}$ in $\mathrm{N}_{2}$ were used. A constant water vapor concentration of $0.5 \%$ was fed in all the experiments.

The uncertainty in the experimental procedure was analyzed and selected experiments were repeated on different, not consecutive days. Repeated experiments were in agreement within $8 \%$. The overall experimental uncertainty is dominated by the uncertainty in the temperature and is estimated to be $\pm 30 \%$. 


\section{Chemical Kinetic Model}

The chemical kinetic model was based on previous work by the authors on nitrogen chemistry, i.e., [39-42]. In the present work, reactions involved in thermal NO formation were re-evaluated. The thermodynamic properties were adopted from the Ideal Gas Thermochemical Database by Goos, Burcat and Ruscic [43]. For the species involved in the rate-limiting step (R1), i.e. $\mathrm{O}, \mathrm{N}, \mathrm{NO}$, and $\mathrm{N}_{2}$ (see Table 1), the uncertainty in the thermochemistry is negligible. For example, the accuracy in the heat of formation at 298 $\mathrm{K}$ for ground state atomic nitrogen has been calculated to be better than $\pm 0.001 \mathrm{kcal} \mathrm{mol}^{-1}$ [43], using the Active Thermochemical Tables (ATcT) approach $[44,45]$.

Table 2 lists selected reactions important for the formation of $\mathrm{NO}$ in $\mathrm{H}_{2} / \mathrm{O}_{2} / \mathrm{N}_{2}$ mixtures at high temperature. In addition to the reactions in thermal $\mathrm{NO}$ formation (R1-R3), subsets are included for formation of $\mathrm{NO}$ via $\mathrm{N}_{2} \mathrm{O}$ (R4R9) and via NNH (R10-R24).

The rate constant for the key reaction in thermal NO formation,

$$
\mathrm{O}+\mathrm{N}_{2} \rightleftharpoons \mathrm{NO}+\mathrm{N}
$$

was based on an evaluation of the present experimental data as well as data from literature. This is discussed in detail below.

Once formed, atomic nitrogen is rapidly oxidized to $\mathrm{NO}$ in presence of $\mathrm{OH}$ and/or $\mathrm{O}_{2}$,

$$
\begin{aligned}
& \mathrm{N}+\mathrm{OH} \rightleftharpoons \mathrm{NO}+\mathrm{H} \\
& \mathrm{N}+\mathrm{O}_{2} \rightleftharpoons \mathrm{NO}+\mathrm{O}
\end{aligned}
$$

Under oxidizing conditions, these steps are fast, and reaction (R1) is the ratelimiting step in thermal NO formation. However, under reducing conditions or in the presence of considerable amounts of $\mathrm{NO}$ (where reaction $\mathrm{N}+\mathrm{NO}$ $\rightleftharpoons \mathrm{O}+\mathrm{N}_{2}$ (R1b) becomes competitive), the rate constants of (R2) and (R3) may become important for the NO formation rate.

The only direct measurements of $\mathrm{k}_{2}$ are at low temperatures [48-52]. At 300 $\mathrm{K}$ the data are in good agreement, with the measurements of the temperature coefficient of $\mathrm{k}$ suggesting a small negative dependence $[49,51,52]$. At high 
temperatures, $\mathrm{k}_{2}$ can be derived from shock tube measurements [53-57] and flow reactor measurements [58] of the reverse step, $\mathrm{H}+\mathrm{NO} \rightleftharpoons \mathrm{N}+\mathrm{OH}$ (R2b). The high temperature data are more scattered, but they support a value of $\mathrm{k}_{2}$ that is slightly larger than the room temperature determinations. We have chosen the recommendation of Miller et al. [59] of a temperatureindependent value of $\mathrm{k}_{2}$ of $3.8 \times 10^{13} \mathrm{~cm}^{3} \mathrm{~mol}^{-1} \mathrm{~s}^{-1}$. It was based on the low-temperature data of Howard and Smith $[48,49]$ and the high-temperature results from Flower et al. [57], and it is in agreement with other reported data sets within the uncertainty.

Contrary to the situation for $\mathrm{k}_{1}$ and $\mathrm{k}_{2}$, measurements of the rate constant for the $\mathrm{N}+\mathrm{O}_{2}$ reaction ( $\mathrm{R} 3$ ) are in good agreement over a wide temperature range. These data have been reviewed by Baulch et al. [35]. They recommend the rate constant derived by Fernandez et al. [46] which provides an excellent fit to the reported experimental results.

The $\mathrm{N}_{2} \mathrm{O}$ and $\mathrm{NNH}$ subsets were drawn from the recent work of Klippenstein et al. [42]. In the temperature range of the present study, modeling predictions are sensitive to the reaction,

$$
\mathrm{N}_{2} \mathrm{O}+\mathrm{O} \rightleftharpoons \mathrm{NO}+\mathrm{NO}
$$

The rate constant for ( $\mathrm{R} 6$ ) has been controversial, possibly due to $\mathrm{H}_{2} \mathrm{O}$ contamination on $\mathrm{N}_{2} \mathrm{O}$ shock tube studies. Meagher and Anderson [60] reviewed the available experimental results carefully, and we have adopted their value for $\mathrm{k}_{6}$, which is also supported by Baulch et al. [35].

\section{Results and Discussion}

\section{Determination of the rate constants $k_{1}$ and $k_{1 b}$}

We have conducted flow reactor experiments for $\mathrm{N}_{2} / \mathrm{O}_{2}$ mixtures in the temperature range $1700-1800 \mathrm{~K}$ and at atmospheric pressure, varying the $\mathrm{O}_{2}$ mole fraction in the range $0.45 \%$ to $20.9 \%$ and monitoring the NO formation. The measured outlet NO concentrations from the experiments are shown in Table 3 . 
The experimental results were interpreted by the detailed chemical model discussed above and used to determine the rate constant for the reaction,

$$
\mathrm{O}+\mathrm{N}_{2} \rightleftharpoons \mathrm{NO}+\mathrm{N}
$$

For the modeling analysis, plug flow behavior of the reactor was assumed. Computations were conducted using Chemkin-PRO [61]. With the detailed mechanism and using the temperature profile shown in Figure 1, we have adjusted $\mathrm{k}_{1}$ for each condition to get the best fit according to the present experimental NO data.

In the kinetic analysis, the fitting involved the data of the 1.8, 8.0, and $20.9 \% \mathrm{O}_{2}$ in $\mathrm{N}_{2}$ mixtures over the $1700-1800 \mathrm{~K}$ temperature range (sets $2-4$ in Table 3). The full temperature profile inside the reactor for each experiment was used for calculations. The temperature range of the experiments is too narrow to determine the activation energy for (R1) accurately. Instead, we fixed $\mathrm{E}_{\mathrm{a}}$ at the recommended value of $76.1 \mathrm{kcal} \mathrm{mol}^{-1}$ [35] and determined the pre-exponential factor $\mathrm{A}$ for each condition. The measured values of $\mathrm{A}$ are shown in Figure 2. Here, each value of $\mathrm{A}$ is associated with the peak temperature of the specific experiment. The scatter in the values of A derived from the detailed modeling is well below a factor of 1.5. From a least-squares fit, we obtain a value of $\mathrm{k}_{1}=1.4 \cdot 10^{14} \exp (-38300 / \mathrm{T}) \mathrm{cm}^{3} \mathrm{~mol}^{-1} \mathrm{~s}^{-1}$.

Figure 3 compares modeling predictions obtained using the present value of $\mathrm{k}_{1}$ with the measured NO concentrations. In this comparison all NO results from sets 1 to 4 have been used. As expected, the observed NO concentrations are captured well by the model.

Sensitivity and reaction path analysis were performed to delineate the important reactions influencing the thermal NO formation process. In the initial stage, partial equilibrium between atomic and molecular oxygen is rapidly attained. The formation of $\mathrm{O}$ is facilitated by the sequence,

$$
\begin{gathered}
\mathrm{O}_{2}+\mathrm{H}_{2} \mathrm{O} \longrightarrow \mathrm{HO}_{2}+\mathrm{OH} \\
\mathrm{HO}_{2}(+\mathrm{M}) \longrightarrow \mathrm{H}+\mathrm{O}_{2}(+\mathrm{M})
\end{gathered}
$$

These reactions, followed by $\mathrm{H}+\mathrm{O}_{2} \rightleftharpoons \mathrm{O}+\mathrm{OH}, \mathrm{OH}+\mathrm{OH} \rightleftharpoons \mathrm{H}_{2} \mathrm{O}+\mathrm{O}$, promote establishment of the radical pool. The subsequent formation of NO occurs mainly through the Zeldovich mechanism. At the first stage of the 
reaction, NO is formed by reactions (R1) and (R3),

$$
\begin{aligned}
& \mathrm{O}+\mathrm{N}_{2} \rightleftharpoons \mathrm{NO}+\mathrm{N} \\
& \mathrm{N}+\mathrm{O}_{2} \rightleftharpoons \mathrm{NO}+\mathrm{O}
\end{aligned}
$$

and to a lesser extent by a reaction sequence involving $\mathrm{N}_{2} \mathrm{O}$,

$$
\begin{gathered}
\mathrm{N}_{2} \mathrm{O}(+\mathrm{M}) \rightleftharpoons \mathrm{N}_{2}+\mathrm{O}(+\mathrm{M}) \\
\mathrm{N}_{2} \mathrm{O}+\mathrm{O} \rightleftharpoons \mathrm{NO}+\mathrm{NO},
\end{gathered}
$$

However, as the reaction advances other minor steps also become active, including the $\mathrm{N}+\mathrm{OH}$ reaction (R2). There is some $\mathrm{NO} / \mathrm{NO}_{2}$ interconversion through the sequence $\mathrm{NO}+\mathrm{O}(+\mathrm{M}) \rightleftharpoons \mathrm{NO}_{2}(+\mathrm{M}), \mathrm{NO}_{2}+\mathrm{O} \rightleftharpoons \mathrm{NO}+\mathrm{O}_{2}$, but these reactions do not contribute to net $\mathrm{NO}$ formation.

Figure 4 shows the first order sensitivity coefficients for the predicted NO formation for the $20.9 \% \mathrm{O}_{2}$ mixture at $1707 \mathrm{~K}, 1758 \mathrm{~K}$ and $1807 \mathrm{~K}$, respectively. The predicted formation of $\mathrm{NO}$ is sensitive mostly to reaction (R1) and to a smaller degree to reaction (R6). Also the steps $\mathrm{HO}_{2}(+\mathrm{M}) \rightleftharpoons \mathrm{H}+$ $\mathrm{O}_{2}(+\mathrm{M})$ and $\mathrm{H}_{2} \mathrm{O}+\mathrm{O}_{2} \rightleftharpoons \mathrm{HO}_{2}+\mathrm{OH}$ show up in the sensitivity analysis, but only with small sensitivity coefficients. The results confirm that, under the conditions of the present work, reaction (R1) is the main bottleneck in the thermal NO formation. The relative importance of the side reactions depends on the temperature. The impact of uncertainties in side-reactions, $\mathrm{U}_{\mathrm{sr}}$, has been determined by scaling the individual uncertainties of these reactions with their sensitivity coefficients according to Equation 1,

$$
\mathrm{U}_{\mathrm{sr}, 1}=\sqrt{\sum_{\mathrm{i}}\left(\mathrm{S}_{\mathrm{NO}, \mathrm{i}} \frac{\Delta \mathrm{k}_{\mathrm{i}}}{\mathrm{k}_{\mathrm{i}}}\right)^{2}} /\left(\mathrm{S}_{\mathrm{NO}, 1}\right), \mathrm{i} \neq 1
$$

Here, $\mathrm{S}_{\mathrm{NO}, \mathrm{i}}$ represents the sensitivity coefficient for the $\mathrm{i}^{\text {th }}$ reaction included in the sensitivity analysis for NO formation except for the investigated reaction $(\mathrm{i}=1)$. Thus, $\mathrm{i}$ corresponds to $\mathrm{N}_{2}+\mathrm{O}(\mathrm{R} 6), \mathrm{HO}_{2}(+\mathrm{M})$, and $\mathrm{H}_{2} \mathrm{O}+$ $\mathrm{O}_{2}$. The factor $\Delta \mathrm{k}_{\mathrm{i}} / \mathrm{k}_{\mathrm{i}}$ represents the uncertainty associated with the $\mathrm{i}^{\text {th }}$ reaction; these were mostly drawn from Baulch et al. [35]. For the most important side reaction (R6), Baulch et al. report error limits, quoted as $\Delta \log \left(\mathrm{k}_{6}\right)$, of \pm 0.2 at $2000 \mathrm{~K}$ rising to \pm 0.3 at $4000 \mathrm{~K}$ and \pm 0.4 at 1000 $\mathrm{K}$. Considering that the present experimental work has been performed over 
the 1700-1800 K temperature range, we have evaluated the sensitivity of the process to variations in $\Delta \log \left(\mathrm{k}_{6}\right)$ of \pm 0.25 . Taking into account these error limits and the sensitivity coefficients shown in Figure 4, the uncertainty in the determination of the rate constant of reaction arising from uncertainties in side-reactions, $\mathrm{U}_{\mathrm{sr}, 1}$, is about $8 \%$.

The overall uncertainty limit $\mathrm{U}_{\text {tot }, 1}$ is subsequently determined by:

$$
\left.\mathrm{U}_{\mathrm{tot}, 1}=\sqrt{\left(\mathrm{U}_{\mathrm{sr}, 1}\right)^{2}+\left(\mathrm{U}_{\exp }\right)^{2}}\right)
$$

where $U_{\exp }$ is the experimental uncertainty. With the uncertainty in the temperature being dominant an overall uncertainty in $\mathrm{k}_{1}$ of about $30 \%$ has been calculated.

The rate constant $\mathrm{k}_{1}$ for $\mathrm{O}+\mathrm{N}_{2} \rightleftharpoons \mathrm{NO}+\mathrm{N}$ has only been measured directly in the shock tube studies of Monat et al. [6] and Thielen and Roth [7]. These two studies are in good agreement. Values of $\mathrm{k}_{1}$ have also been inferred from a number of flame studies [8-15]. The flame data show significant scatter, presumably due to uncertainties in the flame temperature and in the concentration of atomic oxygen, and we have chosen in the present study to disregard these indirect measurements. Contrary to (R1), the reverse reaction $\mathrm{N}+\mathrm{NO} \rightleftharpoons \mathrm{O}+\mathrm{N}_{2}$ (R1b) has been characterized experimentally over a wide range of conditions [16-34] and direct measurements are available over a temperature range of 48-3660 K. Less accurate indirect determinations of $k_{1 b}$ have been reported from shock tube studies of NO decomposition [62].

Since the rate constant for reaction (R1b) has been more thoroughly characterized experimentally than that of (R1), we focus on $\mathrm{k}_{1 \mathrm{~b}}$ in the following. From the equilibrium constant of the reaction, we convert our values for $k_{1}$ to the corresponding values of $\mathrm{k}_{1 \mathrm{~b}}$. Due to the negligible uncertainty in the thermodynamic properties for the involved species, the loss of accuracy in this conversion is very small.

Figure 5 shows an Arrhenius plot for reaction (R1b). In the figure, each data point represents the mean value at the specified temperature of measurements across the range of $\mathrm{O}_{2}$ concentrations from $1.8 \%$ to $20.9 \%$. Also shown in the figure are the corresponding rate constants derived from the evaluation of Baulch et al. [35]. Baulch et al. stated that their recommendations for the forward and reverse rate constant were in agreement within the 
combined uncertainty (a factor of two for both rate constants). Both sets of rate constants from Baulch et al. are within the $\pm 30 \%$ uncertainty of the present values. However, as seen in the figure, the value for $\mathrm{k}_{1 \mathrm{~b}}$, derived from their recommendation of $\mathrm{k}_{1}$ and the equilibrium constant, is $50 \%$ larger at $1700-1800 \mathrm{~K}$ than their recommended value of $\mathrm{k}_{1 \mathrm{~b}}$. This difference becomes even more pronounced as the temperature increases. For this reason, it is important to obtain values of $\mathrm{k}_{1}$ and $\mathrm{k}_{1 \mathrm{~b}}$ that are internally consistent.

Figure 6 shows an Arrhenius plot for the $\mathrm{N}+\mathrm{NO}$ reaction (R1b) over a broader temperature range, comparing literature data with the values of $\mathrm{k}_{1 \mathrm{~b}}$ derived from the flow reactor experiments of the present work and with our recommended rate constant. For clarity, only selected low-temperature data are shown. There is a substantial scatter in the measurements and a considerable uncertainty about the temperature dependence of the reaction. The low-temperature data were evaluated by Sander et al. [63] and Baulch et al. [35]. Their low-temperature recommendations were based on the discharge flow-resonance fluorescence study of Wennberg and Anderson [33], and the discharge flow-resonance fluorescence and flash photolysis-resonance fluorescence studies of Lee et al. [22]. These studies indicate a value of $\mathrm{k}_{1 \mathrm{~b}}$ at $300 \mathrm{~K}$ of $1.8-2.1 \times 10^{13} \mathrm{~cm}^{3} \mathrm{~mol}^{-1} \mathrm{~s}^{-1}$, in reasonable agreement with measurements by Lin et al. [20], Cheah and Clyne [23], Stief et al. [27], and more recently Bergeat et al. [34].

At intermediate temperatures, measurements have been reported by Clyne and Thrush [17] (476-755 K) from an indirect study and by Clyne and McDermid [21] (298-670 K). According to Cheah and Clyne [23], the scatter in the data from Clyne and McDermid can be attributed to the limited sensitivity of the mass spectrometry technique used to monitor the atomic nitrogen concentration. At high temperatures, $\mathrm{k}_{1 \mathrm{~b}}$ has been derived from shock tube experiments by Davidson and Hanson [28] (1387-3513 K), Koshi et al. [29] (1600-2285 K), Michael and Lim [31] (1251-3152 K), and Mick and Roth [32] $(1660-3360 \mathrm{~K})$. The results are quite scattered, with the data from Koshi et al. falling about $40 \%$ below the other. The results of Michael and Lim, and of Mick and Roth are in agreement, supporting the recommendation of Baulch et al. [35] of a temperature-independent value of $\mathrm{k}_{1 \mathrm{~b}}$ of $2.1 \times 10^{13}$ $\mathrm{cm}^{3} \mathrm{~mol}^{-1} \mathrm{~s}^{-1}$ (210-3700 K) (the long-dashed line in Fig. 6). However, the results of Davidson and Hanson indicate a value of $\mathrm{k}_{1 \mathrm{~b}}$ with a slightly positive temperature coefficient. 
From the equilibrium constant of the reaction, we have converted values for $\mathrm{k}_{1}$ from the shock tube studies of Monat et al. [6] and Thielen and Roth [7] to the corresponding $k_{1 b}$ values and they are also shown in the figure. The agreement between the two shock tube studies is good, and their results formed the basis for the recommendation of $\mathrm{k}_{1}$ from Baulch et al. [35], shown as the long-dashed line in Fig. 6. It is apparent from the figure that the Baulch recommendations for the forward and reverse rate constants become substantially different at high temperatures.

Combination of our results with literature values leads to a recommended rate constant for $\mathrm{k}_{1 \mathrm{~b}}$ of $9.4 \times 10^{12} \mathrm{~T}^{0.14} \mathrm{~cm}^{3} \mathrm{~mol}^{-1} \mathrm{~s}^{-1}$ over the 250-3000 $\mathrm{K}$ range. This value is roughly $25 \%$ above the Baulch recommendation for $\mathrm{k}_{1 \mathrm{~b}}$, while it corresponds to a value $\mathrm{k}_{1}$ of the reverse reaction about $25 \%$ below the Baulch evaluation. Our recommended rate constant is in good agreement with the low temperature data for $\mathrm{N}+\mathrm{NO}(\mathrm{R} 1 \mathrm{~b})$ and agree within uncertainty limits with the shock tube determinations for $\mathrm{N}+\mathrm{NO}$ by Davidson and Hanson [28], Michael and Lim [31], Mick et al. [32], and for O $+\mathrm{N}_{2}$ by Monat et al. [6] and Thielen and Roth [7]. This way, the present value of $\mathrm{k}_{1 \mathrm{~b}}$ reconciles the differences between the forward and reverse rate constant and we recommend it for use in kinetic modeling.

\section{Modeling predictions for thermal NO}

Formation of thermal NO has considerable implications for pollutant emissions in combustion and one would expect that it had been extensively characterized experimentally. However, perhaps due to the simplicity of the mechanism, little experimental work has been conducted to characterize thermal NO formation under well-controlled conditions. Formation of NO from an $\mathrm{O}_{2} / \mathrm{N}_{2}$ mixture at high temperatures has only been reported from a few studies conducted in shock tubes [64,65] and flow reactors [66,67]. These studies generally support the findings of Zeldovich [5] and have attracted little attention.

In addition to the data obtained in $\mathrm{N}_{2} / \mathrm{O}_{2}$ systems, $\mathrm{NO}$ formation has been reported from combustion of $\mathrm{H}_{2}$ in jet-stirred reactors [68,69], shock tubes [70], laminar premixed flames [71-75], and laminar opposed-flow diffusion flames [76]. Data from some of these studies were used for model validation 
by Konnov [77] and by Frassoldati et al. [78]. Unfortunately, most of the reported results are not suitable for purposes of quantifying the thermal NO formation rate, either because the conditions of the experiments were not fully characterized or because the work was conducted under conditions where thermal NO formation was not the main source of NO. This is discussed further below.

In addition to the hydrogen flames, a number of hydrocarbon flames have been used to characterize thermal NO and to estimate the rate constant of (R1) [8-15]. While NO formation in the near-burner region of these flames is likely to be dominated by prompt NO formation, additional NO formed in the post-combustion region can be attributed largely to the thermal NO mechanism. As discussed above, values of $\mathrm{k}_{1}$ derived from flame data show significant scatter, presumably due to uncertainties in the determination of flame temperature and atomic oxygen concentration. It should also be noted [14] that in the post-flame region, pronounced radial temperature gradients develop due to heat losses to the surroundings. Because of the strong temperature-dependence of the rate of reaction $(\mathrm{R} 1)$, radial [NO] gradients will also gradually develop and the additional NO formed in the hotter central parts of the flame will diffuse to the outer cooler regions. Due to these uncertainties, flame data can only be used cautiously for model evaluation.

In the following, we compare modeling predictions using the detailed chemical kinetic model with experimental results obtained in flow reactors, jet-stirred reactors, shock tubes, and laminar premixed flames. The aim of this part of the study is to verify that the mechanism, with the present value of $k_{1}$, is compatible with experimental data for the thermal NO formation rate over a wide range of conditions.

\section{Formation of $\mathrm{NO}$ from $\mathrm{O}_{2} / \mathrm{N}_{2}$ in a flow reactor}

In addition to the present work, formation of $\mathrm{NO}$ from reaction of $\mathrm{O}_{2}$ and $\mathrm{N}_{2}$ at high temperature in flow reactors has been studied by Arai et al. [66] and by Tomeczek and Gradon [67]. Tomeczek and Gradon reported NO formation rates from oxygen/nitrogen mixtures in the 1653-1798 $\mathrm{K}$ range that apparently were too high to be explained in terms of the Zeldovich mechanism, i.e. reactions (R1) to (R3). They attributed the additional NO 
formation to the nitrous oxide mechanism, i.e.,

$$
\begin{gathered}
\mathrm{N}_{2}+\mathrm{O}(+\mathrm{M}) \rightleftharpoons \mathrm{N}_{2} \mathrm{O}(+\mathrm{M}) \\
\mathrm{N}_{2} \mathrm{O}+\mathrm{O} \rightleftharpoons \mathrm{NO}+\mathrm{NO},
\end{gathered}
$$

assigning a very high rate constant for reaction (R6). As discussed elsewhere $[60,79]$, this value is incompatible with available experimental data, and while the source of the large NO formation rate observed by Tomeczek and Gradon is still unexplained. For this reason, we choose to disregard this data set in our evaluation.

Arai et al. [66] conducted an experimental study of the $\mathrm{O}_{2} / \mathrm{N}_{2}$ system in an isothermal laminar flow reactor, investigating the effect of the $\mathrm{O}_{2} / \mathrm{N}_{2}$ ratio and the temperature on the formation of NO. The reactor consisted of an alumina tube of length $700 \mathrm{~mm}$ and diameter $20 \mathrm{~mm}$, located in an electrically heated oven with 10 silicon carbide heating elements. The temperature along the center axis of the reactor was measured by a PR-13 thermocouple. The NO concentrations in the outlet gas from the reactor were measured continuously by a chemiluminescence analyzer. The reaction temperature covered the range $1550-1750 \mathrm{~K}$ while the $\mathrm{O}_{2}$ mole fraction $\left(\mathrm{O}_{2} /\left(\mathrm{N}_{2}+\mathrm{O}_{2}\right)\right)$ ranged from 0 to 1.0. Measurements confirmed that an isothermal region of about $39 \mathrm{~cm}$ for $\mathrm{T}=\mathrm{T}_{\text {iso }} \pm 80 \mathrm{~K}$ was established in the reactor. Due to the sensitivity of the thermal NO mechanism towards the temperature, in the present study we have conducted calculations with the full measured temperature profile for reference, finding a corresponding length of an isothermal zone slightly longer than that of Arai et al.

Figure 7 compares the measured NO concentrations reported by Arai et al. with modeling predictions. Calculations with the present kinetic model are shown as solid lines while long-dashed lines lines and short-dashed denote predictions with recommended rate constants for (R1) and (R1b), respectively, from Baulch et al. [35]. Over the full range of temperature (1569-1723 $\mathrm{K})$ and $\mathrm{O}_{2}$ mole fractions (0.05-0.95), the modeling predictions agree with the experimental results within $20 \%$ or better. The only differences are found at the highest temperature at $\mathrm{O}_{2}$ levels above $30 \%$, where the predicted $\mathrm{NO}$ levels exceed the measurements. At this temperature the observed NO profile has a different shape from those measured at other temperatures, with NO peaking at lower $\mathrm{O}_{2}$ concentrations, and the difference may be partly 
attributed to an experimental artifact. Comparison of modeling predictions with the rate constant for (R1) drawn from Baulch et al. indicate that their value of $\mathrm{k}_{1}$ is too large.

\section{Formation of NO from $\mathbf{H}_{2}$ oxidation in a jet-stirred reactor}

Results on formation of $\mathrm{NO}$ from combustion of $\mathrm{H}_{2}$ in jet-stirred reactors have been reported by Engleman et al. [68] and by Xie et al. [69]. The jetstirred reactor data of Xie et al. were obtained at temperatures of 1400-1550 $\mathrm{K}$. Under these conditions the $\mathrm{N}_{2} \mathrm{O}$ mechanism controls the $\mathrm{NO}$ formation and these data were not considered further in the present work.

Engleman et al. [68] studied formation of NO in a jet-stirred reactor for oxidation of hydrogen, carbon monoxide and propane. The combustion experiments were conducted at atmospheric pressure at residence times in the range 1.5-4.0 msec. Gas temperatures could be measured within $\pm 10 \mathrm{~K}$ up to about $2040 \mathrm{~K}$ with a $\mathrm{Pt} / \mathrm{Pt}-10 \% \mathrm{Rh}$ thermocouple. At temperatures above this value, Engleman et al. relied on a heat balance equation, with an overall heat transfer coefficient fitted to match experimental data.

Figure 8 compares measured NO concentrations from Engleman et al. from combustion of hydrogen over a range of fuel-air equivalence ratios of $0.7 \leq \phi \leq$ 1.55. For the calculations, the reactor temperatures reported by Engleman et al. were used. Unfortunately, at values of $\phi$ in the range 0.95-1.3 the reactor temperature exceeded that allowable for continuous operation of the combustor. Under these conditions only shortened duration of testing was conducted and it is uncertain whether thermal equilibrium was attained. We consider the data obtained in these conditions (shown as open circles in the figure) to be less reliable than measurements conducted at lower temperatures (closed circles).

The model predicts well the NO levels at conditions with excess $\mathrm{O}_{2}(\phi=0.7)$ or excess fuel $(\phi \geq 1.1)$. However, close to stoichiometric conditions, NO is overpredicted by a factor of two or more. We attribute this difference mainly to the uncertainty in the temperature. Predictions with the $\mathrm{k}_{1}$ and $\mathrm{k}_{1 \mathrm{~b}}$ from Baulch et al. [35] (dashed lines) are probably also with the experimental uncertainty, even though they differ significantly. 


\section{Formation of $\mathrm{NO}$ from $\mathrm{H}_{2}$ oxidation in a shock tube}

Shock tube results for thermal NO have been reported for $\mathrm{O}_{2} / \mathrm{N}_{2}$ mixtures by Glick et al. [64] and by Camac and Feinberg [65]. Unfortunately the data from these studies were reported in a form which make them difficult to utilize for model evaluation. On the other hand, the shock tube results from Bowman [70] for $\mathrm{NO}$ formation from $\mathrm{H}_{2}$ oxidation at high temperatures are useful, since both reaction conditions and product composition are well characterized.

Bowman [70] conducted reflected shock tube experiments for $\mathrm{H}_{2}$ oxidation in $\mathrm{O}_{2} / \mathrm{N}_{2}$, using spectroscopic techniques to monitor the concentrations of $\mathrm{NO}, \mathrm{OH}$ and $\mathrm{H}_{2} \mathrm{O}$ as a function of time. The absorption optical system was calibrated to give the concentrations of NO in the $v=1$ and $v=2$ vibrational states to minimize interference from absorption of $\mathrm{O}_{2}$. The concentration of NO was then determined from assuming local vibrational equilibration. The uncertainty in the reflected shock temperature was estimated to be $\pm 50 \mathrm{~K}$.

In the present work, we have simulated the $\mathrm{NO}(v=1)$ concentration as a function of time and compared to the experimental results. Under the experimental conditions, $\mathrm{NO}$ and $\mathrm{NO}(v=1)$ are rapidly equilibrated through the reaction,

$$
\mathrm{NO}+\mathrm{O} \rightleftharpoons \mathrm{NO}(v=1)+\mathrm{O}
$$

Both the excitation and the relaxation reaction has been studied over a wide temperature range (see [80-82]) and the rate constant is known probably within a factor of two. Calculations with this reaction added to the reaction mechanism confirms the assumption of Bowman that the vibrational states of NO are rapidly equilibrated, and modeling predictions are not sensitive to the relaxation rate constant.

Experiments were conducted under oxidizing and reducing conditions, respectively. Figure 9 compares measured and predicted concentration profiles for $\mathrm{OH}$ and $\mathrm{NO}(v=1)$ for the lean experiment, conducted at $2560 \mathrm{~K}$. This experiment was conducted with $2 \% \mathrm{H}_{2}$ and $6 \% \mathrm{O}_{2}$, with a considerable dilution in $\mathrm{N}_{2}$ to reduce temperature and pressure changes during reaction.

The predicted concentration profiles for $\mathrm{OH}$ and $\mathrm{NO}$ are in excellent agreement with the experiments. The oxidation of the $\mathrm{H}_{2}$ occurs on very short 
times scales compared to the 1 msec monitoring time. The $\mathrm{OH}$ concentration peaks almost instantaneously and then declines slowly. Little $\mathrm{NO}(v=1)$ is formed during the $\mathrm{H}_{2}$ consumption period, but $[\mathrm{NO}(v=1)]$ increases slowly with time, consistent with the comparatively slow thermal NO formation mechanism. The dashed lines in the figure denote predictions with the $\mathrm{k}_{1}$ and $\mathrm{k}_{1 \mathrm{~b}}$ from Baulch et al. [35]. They deviate more from the observed $\mathrm{NO}(v=1)$ most pronounced for $\mathrm{k}_{1 \mathrm{~b}}$.

\section{Formation of NO from $\mathrm{H}_{2}$ oxidation in a laminar premixed flame}

A wide range of flame studies focusing on thermal NO has been reported in literature, but results for hydrogen flames are limited. Laminar premixed flame studies for $\mathrm{H}_{2} / \mathrm{O}_{2} / \mathrm{N}_{2}$ have been conducted by Shahed and Newhall [71], Homer and Sutton [72], Hoyermann et al. [73], Harrington et al. [74], and Shmakov et al. [75]. Neither Shahed and Newhall nor Hoyermann et al. report measured temperature profiles for the $\mathrm{H}_{2}$ flames. Harrington et al. and Shmakov et al. provide detailed temperature and concentration profile measurements, but these studies were conducted at temperatures where thermal NO formation is insignificant. Harrington et al. specifically designed their flame conditions to augment formation of NO through the NNH mechanism, while Shmakov et al. only reported NO measurements for flames doped with $\mathrm{NO}$ or $\mathrm{NH}_{3}$. Only the study of Homer and Sutton, discussed below, is regarded as suitable for the present purposes. In addition to the premixed flame studies, Rørtveit et al. [76] measured NO in laminar opposed-flow hydrogen diffusion flames. They reported that their measurements were affected by catalytic reactions on the surface of their probe and for this reason, we have disregarded them in the present work.

Homer and Sutton [72] reported measurements of NO concentration profiles in atmospheric-pressure premixed hydrogen-oxygen-nitrogen flames over a range of stoichiometries and temperatures. The flame temperatures were measured by the sodium line reversal technique and were found to be about $30 \mathrm{~K}$ below the adiabatic flame temperature. Gas was sampled with a silica probe along the centeraxis of the flames. The NO concentration was determined by oxidizing $\mathrm{NO}$ to $\mathrm{NO}_{2}$ over a catalyst and quantifying $\mathrm{NO}_{2}$.

Both Konnov [77] and Frassoldati et al. [78] previously modeled the data 
from Homer and Sutton as part of a model validation. In their comparison with experiments, they modeled the full flame. Konnov assumed adiabatic conditions and calculated the temperature profile, while Frassoldati et al. did not list their assumptions about the temperature profile. However, the atmospheric pressure flames are heavily stabilized on the burner and conceivably the burner surface affects the flames by removing heat and radicals from the flame zone. Most of the NO formation reported by Homer and Sutton occurs very early in the flame, i.e. in a region where the flame may interact with the burner surface. To minimize this uncertainty, we choose in the calculations to fixate the NO level at the measured value at about $0.25 \mathrm{~cm}$ above the burner and model the NO formation only in the post-flame region. This is done by calculating the NO profile for the full flame and subtract a fixed amount of ppm from the calculated values to match the measured NO concentration at the specified flame location.

Figure 10 compares the data of Homer and Sutton with the modeling predictions. The flame data are scattered and there is some uncertainty in the measured flame temperatures. However, the agreement between observed and calculated NO concentrations in the post-flame region is good. Predictions with the $\mathrm{k}_{1}$ and $\mathrm{k}_{1 \mathrm{~b}}$ from Baulch et al. [35] (dashed lines) are less accurate but still within the scatter of the experimental data.

\section{Conclusions}

In the present work, laboratory flow reactor experiments are performed under well controlled conditions on NO formation from oxygen/nitrogen mixtures, varying temperature and $\mathrm{O}_{2}$ concentration. The results are used to derive an accurate value of the rate constant for the $\mathrm{N}_{2}+\mathrm{O} \rightleftharpoons \mathrm{NO}+\mathrm{N}$ reaction (R1), allowing for reliable predictions of thermal NO formation in combustion. The value of $\mathrm{k}_{1}=1.4 \cdot 10^{14} \exp (-38300 / \mathrm{T}) \mathrm{cm}^{3} \mathrm{~mol}^{-1} \mathrm{~s}^{-1}$ is determined from a least-squares fit of data obtained from a modeling interpretation of the experiments at 1700-1800 K. The estimated uncertainty in the determination of $\mathrm{k}_{1}$ is $\pm 30 \%$ in the temperature range considered. Combination of our results with literature values allow us to recommend a value of the rate constant for the reverse reaction, $\mathrm{k}_{1 \mathrm{~b}}$, of $9.4 \times 10^{12} \mathrm{~T}^{0.14} \mathrm{~cm}^{3} \mathrm{~mol}^{-1} \mathrm{~s}^{-1}$ over the $250-3000 \mathrm{~K}$ range. This rate constant has a slight positive temperature 
coefficient, reconciling the differences between the forward and reverse rate constants given in the evaluation by Baulch et al., and we recommend it for use in kinetic modeling. Predictions with an updated mechanism for thermal $\mathrm{NO}$ are in good agreement with results from literature, including data from flow reactors, jet-stirred reactors, reflected shock tubes, laminar flames, and over a wide range of operating conditions.

\section{Acknowledgements}

The authors express their gratitude to the Aragon Government (GPT group) and to MINECO and FEDER (Project CTQ2012-34423) for financial support.

\section{References}

[1] Miller, J.A.; Bowman, C.T. Prog Energy Combust Sci 1989, 15, 287-338.

[2] Bowman, C.T. Proc Combust Inst 1992, 24, 859-878.

[3] Glarborg, P.; Jensen, A.D.; Johnsson, J.E. Prog Energy Combust Sci 2003, 29, 89-113.

[4] Glarborg, P.; Proc Combust Inst 2007, 31, 77-98.

[5] Zeldovich, Y.B. Acta Physicochem USSR 1946, 21, 577-628.

[6] Monat, J.P.; Hanson, R.K.; Kruger, C.H. Proc Combust Inst 1979, 17, 543.

[7] Thielen, K.; Roth, P. Proc Combust Inst 1984, 20, 685.

[8] Fenimore, C.P. Proc Combust Inst 1971, 13, 373-380.

[9] Livesey, J.B.; Roberts, A.L.; Williams, A. Combust Sci Technol 1971, 4, 9-15.

[10] Bachmaier, F.; Eberius, K.H.; Just, Th. Combust Sci Technol 1973, 7, 77.

[11] Iverach, D.; Basden, K.S.; Kirov, N.Y. Proc Combust Inst 1973, 14, 767.

[12] Harris, R.J.; Nasralla, M.; Williams, A. Combust Sci Technol 1976, 14, 85.

[13] Heberling, P.V. Proc Combust Inst 1977, 16, 159-166.

[14] Blauwens, J.; Smets, B.; Peeters, J. Proc Combust Inst 1977, 16, 1055.

[15] Zabielski, M.F.; Seery, D.J. Fossil Fuels Combust Symp 1989, 25, 91-94.

[16] Herron, J.T. J Chem Phys 1961, 35, 1138.

[17] Clyne, M.A.A.; Thrush, B.A. Proc R Soc London 1961, 261, 259-273.

[18] Phillips, L.F.; Schiff, H.I. J Chem Phys 1962, 36, 1509.

[19] Takezaki, Y.; Mori, S. Bull Inst Chem Res Kyoto Univ 1967, 45, 388. 
[20] Lin, C-L.; Parkes, D.A.; Kaufman, F. J Chem Phys 1970, 53, 3896-3900.

[21] Clyne, M.A.A.; McDermid, I.S. J Chem Soc Faraday Trans 1 1975, 71, 2189.

[22] Lee, J.H.; Michael, J.V.; Payne, W.A.; Stief, L.J. J Chem Phys 1978, 69, 3069.

[23] Cheah, C.T.; Clyne, M.A.A. J Chem Soc Faraday Trans 2 1980, 76, 1543.

[24] Sugawara, K.; Ishikawa, Y.; Sato, S. Bull Chem Soc Jpn 1980, 53, 3159.

[25] Husain, D.; Slater, N.K.H. J Chem Soc Faraday 2 1980, 76, 606.

[26] Brunning, J.; Clyne, M.A.A. J Chem Soc Faraday Trans 2 1984, 80, 1001.

[27] Stief, L.J.; Marston, G.; Nava, D.F.; Payne, W.A., Nesbitt, F.L. Chem Phys Lett 1988, 147, 570 .

[28] Davidson,D.F.; Hanson, R.K. Int J Chem Kinet 1990, 22, 843.

[29] Koshi, M.; Yoshimura, M.; Fukuda, K.; Matsui, H.; Saito, K.; Watanabe, M.; Imamura, A.; Chen, C. J Chem Phys 1990, 93, 8703-8708.

[30] Jeoung, S.C.; Choo, K.Y.; Benson, S.W. J Phys Chem 1991, 95, 7282-7290.

[31] Michael, J.V.; Lim, K.P. J Chem Phys 1992, 97, 3228-3234.

[32] Mick, H.J.; Matsui, H.; Roth, P. J Phys Chem 1993, 97, 6839-6842.

[33] Wennberg, P.O.; Anderson, J.G.; Weisenstein, D.K. J Geophys Res 1994, 99, 18839.

[34] Bergeat, A.; Hickson, K.M.; Daugey, N.; Caubet, P.; Costes, M. Phys Chem Chem Phys 2009, 11, 8149-8155.

[35] Baulch, D.L.; Bowman, C.T.; Cobos, C.J.; Cox, R.A.; Just, T.; Kerr, J.A.; Pilling, M. J., Stocker, D.; Troe, J.; Tsang, W.; Walker, R.W.; Warnatz, J. J Phys Chem Ref Data 2005, 34, 757-1397.

[36] Abián, M.; Giménez-López, J.; Bilbao, R.; Alzueta, M.U. Proc Combust Inst 2011, $33,317-323$.

[37] Giménez-López, J.; Martínez, M.; Millera, A.; Bilbao, R.; Alzueta, M.U. Combust. Flame 158 (2011) 48-56.

[38] Winter, E.R.S. J Cat 22 (1971) 158-170.

[39] Glarborg, P.; Alzueta, M.U.; Dam-Johansen, K.; Miller, J.A. Combust Flame 1998, 115, 1-27.

[40] Glarborg, P.; Kristensen, P.G.; Dam-Johansen, K.; Alzueta, M.U.; Millera, A.; Bilbao, R. Energy Fuels 2000, 14, 828-838.

[41] Skreiberg, O.; Kilpinen, P.; Glarborg, P. Combust Flame 2004, 136, 501-518.

[42] Klippenstein, S.J.; Harding, L.B.; Glarborg, P.; Miller, J.A. Combust Flame 2011, 158, 774-789.

[43] Goos, E.; Burcat, A.; Ruscic, B. Ideal gas thermochemical database with updates from active thermochemical tables (<ftp://ftp.technion.ac.il/pub/supported/aetdd/thermodynamics $>$ mirrored at <http://garfield.chem.elte.hu/burcat/burcat.html>.

[44] B. Ruscic, R.E. Pinzon, R.E; Morton, M.L.; von Laszewski, G.; Bittner, S.; Nijsure, S.G.; Amin, K.A.; Minkoff, M.; Wagner, A.F. J Phys Chem A 2004, 108, 9979-9997.

[45] B. Ruscic, B.; Pinzon, R.E.; von Laszewski, G.; Kodeboyina, D.; Burcat, A.; Leahy, D.; Montoya, D.; Wagner, A.F. J Phys Conf Ser 2005, 16, 561-570.

[46] Fernandez, A.; Goumri, A.; Fontijn, A. J Phys Chem A 1998, 102, 168-172. 
[47] Klippenstein, S.J.; Harding, L.B.; Ruscic, B.; Sivaramakrishnan, R.; Srinivasan, N.K.; Su, M.-C.; Michael, J.V.; J Phys Chem A 2009, 113, 10241-10259.

[48] Howard, M.J.; Smith, I.W.M. Chem Phys Lett 1980, 68, 40.

[49] Howard, M.J.; Smith, I.W.M. J Chem Soc Faraday Trans 2 1981, 77, 997.

[50] Brune, W.H.; Schwab, J.J.; Anderson, J.G. J Phys Chem 1983, 87, 4503.

[51] Smith, I.W.M.; Stewart, D.W.A. J Chem Soc Faraday Trans 1994, 90, 3221.

[52] Bergeat, A.; Daranlot, J.; Hickson, K.M.; Costes, M. EAS Publ Ser 2012, 58, 283286.

[53] Flower, W.L.; Hanson, R.K.; Kruger, C.H. Proc Combust Inst 1975, 15, 823.

[54] Duxbury, J.; Pratt, N.H. Proc Combust Inst 1975, 15, 843.

[55] Koshi, M.; Ando, H.; Oya, M.; Asaba, T. Proc Combust Inst 1975, 15, 909.

[56] Ando, H.; Asaba, T. Int J Chem Kinet 1976, 8, 259.

[57] Flower, W.L.; Hanson, R.K.; Kruger, C.H. Combust Sci Technol 1977, 15, 115.

[58] McCullough, R.W.; Kruger, C.H.; Hanson, R.K. Combust Sci Technol 1977, 15, 213.

[59] Miller, J.A.; Branch, M.D.; McLean, W.J.; Chandler, D.W.; Smooke, M.D.; Kee, R.J. Proc Combust Inst 1985, 20, 673.

[60] Meagher, N.E; Anderson, W.R. J Phys Chem A 2000, 104, 6013-6031.

[61] CHEMKIN-PRO, Release 15082, Reaction Design, San Diego, 2009.

[62] Wray, K.L.; Teare, J.D.; J Chem Phys 1961, 36, 2582-2596.

[63] Sander, S.P.; Friedl, R.R.; Abbatt, J.P.D.; Barker, J.R.; Burkholder, J.B.; Golden, D.M.; Kolb, C.E.; Kurylo, M.J.; Moortgat, G.K.; Wine, P.H.; Huie, R.E.; Orkin, V.L. NASA JPL Publication 10-6, 2011.

[64] Glick, H.S.; Klein, J.J.; Squire, W. J Chem Phys. 1957, 27, 4.

[65] Camac, M.; Feinberg, R.M.; Proc Combust Inst 1967, 11, 137-145.

[66] Arai, N.; Higashi, T.; Hasatani, M.; Sugiyama, S. Int Chem Eng 1978, 18, 661-665.

[67] Tomeczek, J.; Gradon, B.; Combust Sci Technol 1997, 125, 159-180.

[68] Engleman, V.S.; Bartok, W., Longwell, J.P.; Edelman, R.B. Proc Combust Inst 1973, 14, 755-765.

[69] Xie, L.; Hayashi, S.; Hirose, K. Proc Combust Inst 1996, 26, 2155.

[70] Bowman, C.T.; Combust Sci Technol 1971, 3, 37.

[71] Shahed, S.M.; Newhall, H.K. Combust Flame 1971, 17, 131-137.

[72] Homer, J.B.; Sutton, M.M. Combust Flame 1973, 20, 71-76.

[73] Hoyermann, K.; Jander, H.; Wagner, H.G. Ber Bunsenges Phys Chem 1975, 79, 858-868.

[74] Harrington, J.E.; Smith, G.P.; Berg, P.A.; Noble, A.R.; Jeffries, J.B.; Crosley, D.R. Proc Combust Inst 1996, 26, 2133-2138.

[75] Shmakov, A.G.; Korobeinichev, O.P.; Rybitskaya, I.V.; Chernov, A.A.; Knyazkov, D.A.; Bolshova, T.A.; Konnov, A.A. Combustion Flame 2010, 157, 556-565.

[76] Rørtveit, G.J.; Hustad, J.E.; Li, S.C.; Williams, F.A. Combust Flame 2002, 130, 48-61. 
[77] Konnov, A.A. Combust Flame 2003, 134, 421-424.

[78] Frassoldati, A.; Faravelli, T.; Ranzi, E. Int J Hydrogen Energy 2006, 31, 2310-2328.

[79] Konnov, A.A.; De Ruyck, J.; Combust Sci Technol 1999, 149, 53-78.

[80] Dodd, J.A.; Lockwood, R.B.; Hwang, E.S.; Miller, S.M.; Lipson, S.J. J Chem Phys $1999,111,3498$.

[81] Hwang, E.S.; Castle, K.J.; Dodd, J.A. J Geophys Res 2003, 108, 1109.

[82] Galvao, B.R.L.; Corzo-Espinoza, J.A.; Caridade, P.J.S.B.; Varandas, A.J.C. Int J Chem Kinet 2011, 43, 345-352. 


\begin{tabular}{lrrrrrrrrr}
\hline Species & $\mathrm{H}_{298}$ & $\mathrm{~S}_{298}$ & $\mathrm{C}_{\mathrm{p}, 300}$ & $\mathrm{C}_{\mathrm{p}, 400}$ & $\mathrm{C}_{\mathrm{p}, 500}$ & $\mathrm{C}_{\mathrm{p}, 600}$ & $\mathrm{C}_{\mathrm{p}, 800}$ & $\mathrm{C}_{\mathrm{p}, 1000}$ & $\mathrm{C}_{\mathrm{p}, 1500}$ \\
\hline $\mathrm{N}$ & 112.96 & 36.63 & 4.97 & 4.97 & 4.97 & 4.97 & 4.97 & 4.97 & 4.97 \\
$\mathrm{NO}$ & 21.81 & 50.36 & 7.14 & 7.16 & 7.29 & 7.46 & 7.83 & 8.12 & 8.54 \\
$\mathrm{O}$ & 59.55 & 38.49 & 5.23 & 5.13 & 5.08 & 5.05 & 5.02 & 5.00 & 4.98 \\
$\mathrm{~N}_{2}$ & 0.00 & 45.79 & 6.96 & 7.00 & 7.07 & 7.19 & 7.51 & 7.81 & 8.31 \\
\hline
\end{tabular}

Table 1: Thermodynamic properties of selected species in the reaction mechanism. Units are kcal mol ${ }^{-1}$ for $\mathrm{H}$, and cal mol${ }^{-1} \mathrm{~K}^{-1}$ for $\mathrm{S}$ and $\mathrm{C}_{\mathrm{p}}$. Temperatures are in $\mathrm{K}$. 


\begin{tabular}{|c|c|c|c|c|c|}
\hline & & $\begin{array}{r}\mathrm{A} \\
{[\mathrm{cm}, \mathrm{mole}, \mathrm{s}]}\end{array}$ & $\beta$ & $\begin{array}{c}\mathrm{E}_{a} \\
{[\mathrm{cal} / \mathrm{mole}]}\end{array}$ & Source \\
\hline $1 \mathrm{~b}$. & $\mathrm{N}+\mathrm{NO} \rightleftharpoons \mathrm{O}+\mathrm{N}_{2}$ & $9.4 \mathrm{E} 12$ & 0.140 & 0 & See text \\
\hline 2. & $\mathrm{~N}+\mathrm{OH} \rightleftharpoons \mathrm{NO}+\mathrm{H}$ & $3.8 \mathrm{E} 13$ & 0.000 & 0 & {$[41]$} \\
\hline 3. & $\mathrm{~N}+\mathrm{O}_{2} \rightleftharpoons \mathrm{NO}+\mathrm{O}$ & $5.9 \mathrm{E} 09$ & 1.000 & 6280 & {$[46]$} \\
\hline \multirow[t]{3}{*}{4.} & $\mathrm{~N}_{2} \mathrm{O}(+\mathrm{M}) \rightleftharpoons \mathrm{N}_{2}+\mathrm{O}(+\mathrm{M})$ & $1.3 \mathrm{E} 12$ & 0.000 & 62570 & {$[41]$} \\
\hline & Low pressure limit: & 4.0E14 & 0.000 & 56600 & \\
\hline & $\begin{array}{l}\text { Enhanced third-body efficiencies: } \\
\mathrm{N}_{2}=1.7, \mathrm{O}_{2}=1.4, \mathrm{H}_{2} \mathrm{O}=12\end{array}$ & & & & \\
\hline 5. & $\mathrm{~N}_{2} \mathrm{O}+\mathrm{H} \rightleftharpoons \mathrm{N}_{2}+\mathrm{OH}$ & $6.4 \mathrm{E} 07$ & 1.835 & 13492 & {$[42]$} \\
\hline 6. & $\mathrm{~N}_{2} \mathrm{O}+\mathrm{O} \rightleftharpoons \mathrm{NO}+\mathrm{NO}$ & $9.2 \mathrm{E} 13$ & 0.000 & 27679 & [41] \\
\hline 7. & $\mathrm{~N}_{2} \mathrm{O}+\mathrm{O} \rightleftharpoons \mathrm{N}_{2}+\mathrm{O}_{2}$ & $3.7 \mathrm{E} 12$ & 0.000 & 15936 & {$[41]$} \\
\hline 8. & $\mathrm{~N}_{2} \mathrm{O}+\mathrm{OH} \rightleftharpoons \mathrm{N}_{2}+\mathrm{HO}_{2}$ & $1.3 \mathrm{E}-2$ & 4.720 & 36560 & [41] \\
\hline 9. & $\mathrm{~N}_{2} \mathrm{O}+\mathrm{OH} \rightleftharpoons \mathrm{HNO}+\mathrm{NO}$ & $1.2 \mathrm{E}-4$ & 4.330 & 25080 & {$[41]$} \\
\hline 10. & $\mathrm{NNH} \rightleftharpoons \mathrm{N}_{2}+\mathrm{H}$ & $1.0 \mathrm{E} 09$ & 0.000 & 0 & {$[42]$} \\
\hline 11. & $\mathrm{NNH}+\mathrm{H} \rightleftharpoons \mathrm{N}_{2}+\mathrm{H}_{2}$ & $1.0 \mathrm{E} 14$ & 0.000 & 0 & {$[42]$} \\
\hline 12. & $\mathrm{NNH}+\mathrm{O} \rightleftharpoons \mathrm{N}_{2} \mathrm{O}+\mathrm{H}$ & $1.9 \mathrm{E} 14$ & 0.274 & 22 & {$[42]$} \\
\hline 13. & $\mathrm{NNH}+\mathrm{O} \rightleftharpoons \mathrm{N}_{2}+\mathrm{OH}$ & $1.2 \mathrm{E} 13$ & 0.145 & 217 & {$[42]$} \\
\hline 14. & $\mathrm{NNH}+\mathrm{O} \rightleftharpoons \mathrm{NH}+\mathrm{NO}$ & $5.2 \mathrm{E} 11$ & 0.388 & 409 & {$[42]$} \\
\hline 15. & $\mathrm{NNH}+\mathrm{OH} \rightleftharpoons \mathrm{N}_{2}+\mathrm{H}_{2} \mathrm{O}$ & $5.0 \mathrm{E} 13$ & 0.000 & 0 & {$[42]$} \\
\hline 16. & $\mathrm{NNH}+\mathrm{O}_{2} \rightleftharpoons \mathrm{N}_{2}+\mathrm{HO}_{2}$ & $5.6 \mathrm{E} 14$ & -0.385 & 13 & {$[42]$} \\
\hline 17. & $\mathrm{NH}+\mathrm{H} \rightleftharpoons \mathrm{N}+\mathrm{H}_{2}$ & $3.0 \mathrm{E} 13$ & 0.000 & 0 & {$[41]$} \\
\hline 18. & $\mathrm{NH}+\mathrm{O} \rightleftharpoons \mathrm{NO}+\mathrm{H}$ & $9.2 \mathrm{E} 13$ & 0.000 & 0 & {$[41]$} \\
\hline 19. & $\mathrm{NH}+\mathrm{OH} \rightleftharpoons \mathrm{HNO}+\mathrm{H}$ & $3.2 \mathrm{E} 14$ & 0.376 & 46 & {$[47]$} \\
\hline 20. & $\mathrm{NH}+\mathrm{OH} \rightleftharpoons \mathrm{N}+\mathrm{H}_{2} \mathrm{O}$ & $1.6 \mathrm{E} 07$ & 1.733 & 576 & {$[47]$} \\
\hline 21. & $\mathrm{NH}+\mathrm{O}_{2} \rightleftharpoons \mathrm{HNO}+\mathrm{O}$ & 4.6E05 & 2.000 & 6500 & {$[41]$} \\
\hline 22. & $\mathrm{NH}+\mathrm{O}_{2} \rightleftharpoons \mathrm{NO}+\mathrm{OH}$ & $1.3 \mathrm{E} 06$ & 1.500 & 100 & [41] \\
\hline 23. & $\mathrm{NH}+\mathrm{NO} \rightleftharpoons \mathrm{N}_{2} \mathrm{O}+\mathrm{H}$ & $1.8 \mathrm{E} 14$ & -0.351 & -244 & {$[42]$} \\
\hline 24. & $\mathrm{NH}+\mathrm{NO} \rightleftharpoons \mathrm{N}_{2}+\mathrm{OH}$ & $2.7 \mathrm{E} 12$ & -0.072 & -512 & {$[42]$} \\
\hline
\end{tabular}

Table 2: Selected reactions important for thermal NO formation. Parameters for use in the modified Arrhenius expression $\mathrm{k}=\mathrm{AT}^{\beta} \exp (-\mathrm{E} /[\mathrm{RT}])$. Units are mol, cm, s, cal. 


\begin{tabular}{cccccc}
\hline & \multicolumn{5}{c}{$\mathrm{NO}(\mathrm{ppm})$} \\
\hline Temperature & Set 1 & Set 2 & Set 3 & Set 4 & Set 4 (rep) \\
$(\mathrm{K})$ & $0.45 \% \mathrm{O}_{2}$ & $1.8 \% \mathrm{O}_{2}$ & $8.0 \% \mathrm{O}_{2}$ & $20.9 \% \mathrm{O}_{2}$ & $20.9 \% \mathrm{O}_{2}$ \\
\hline 1707 & 3 & 6 & 11 & 16 & 16 \\
1733 & 3 & 12 & 20 & 26 & 27 \\
1758 & 4 & 19 & 36 & 42 & 45 \\
1778 & 8 & 28 & 56 & 65 & 71 \\
1807 & 17 & 46 & 96 & 117 & 118 \\
\hline
\end{tabular}

Table 3: Measured NO exit concentrations for each $\mathrm{O}_{2} / \mathrm{N}_{2}$ mixture at the different reaction temperatures, represented as the maximum temperature in the reactor temperature profile. 


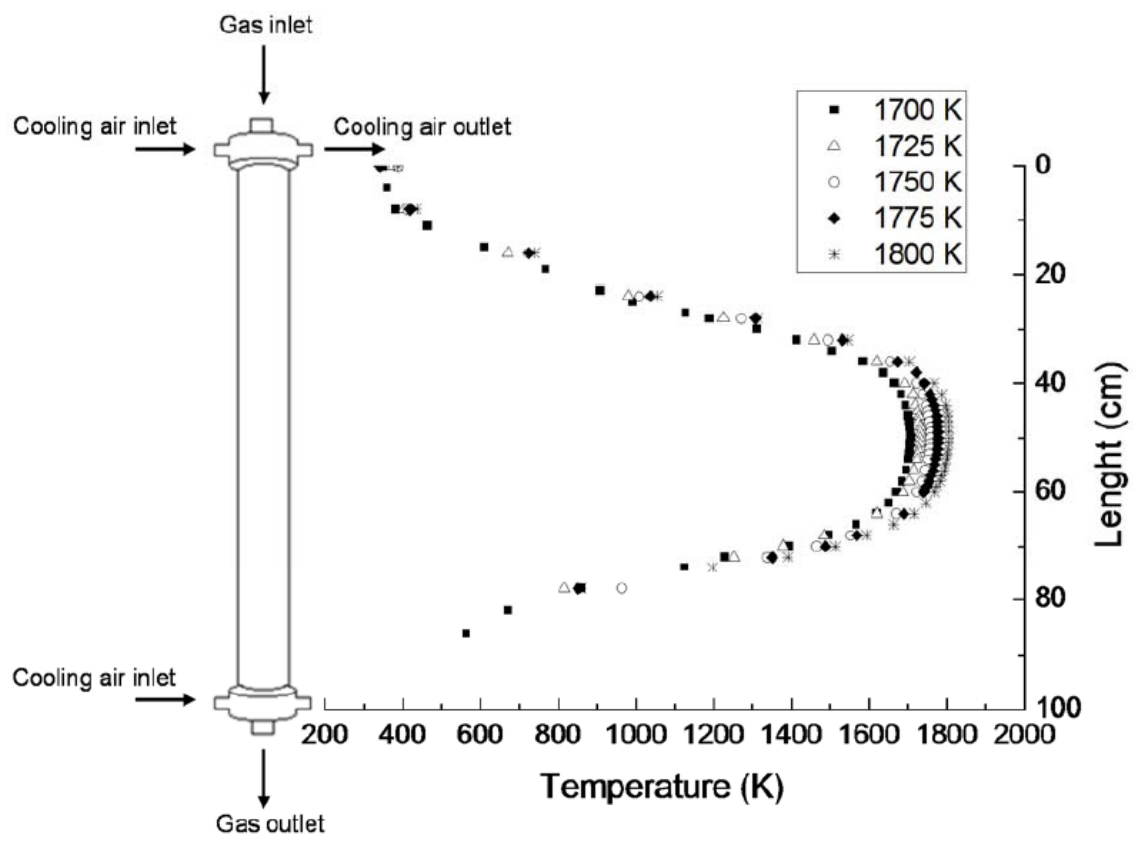

Figure 1: Scheme of the reactor and temperature profiles $(\mathrm{K})$ inside the reactor for selected nominal temperatures of 1700, 1725, 1750, 1775 and $1800 \mathrm{~K}$. 


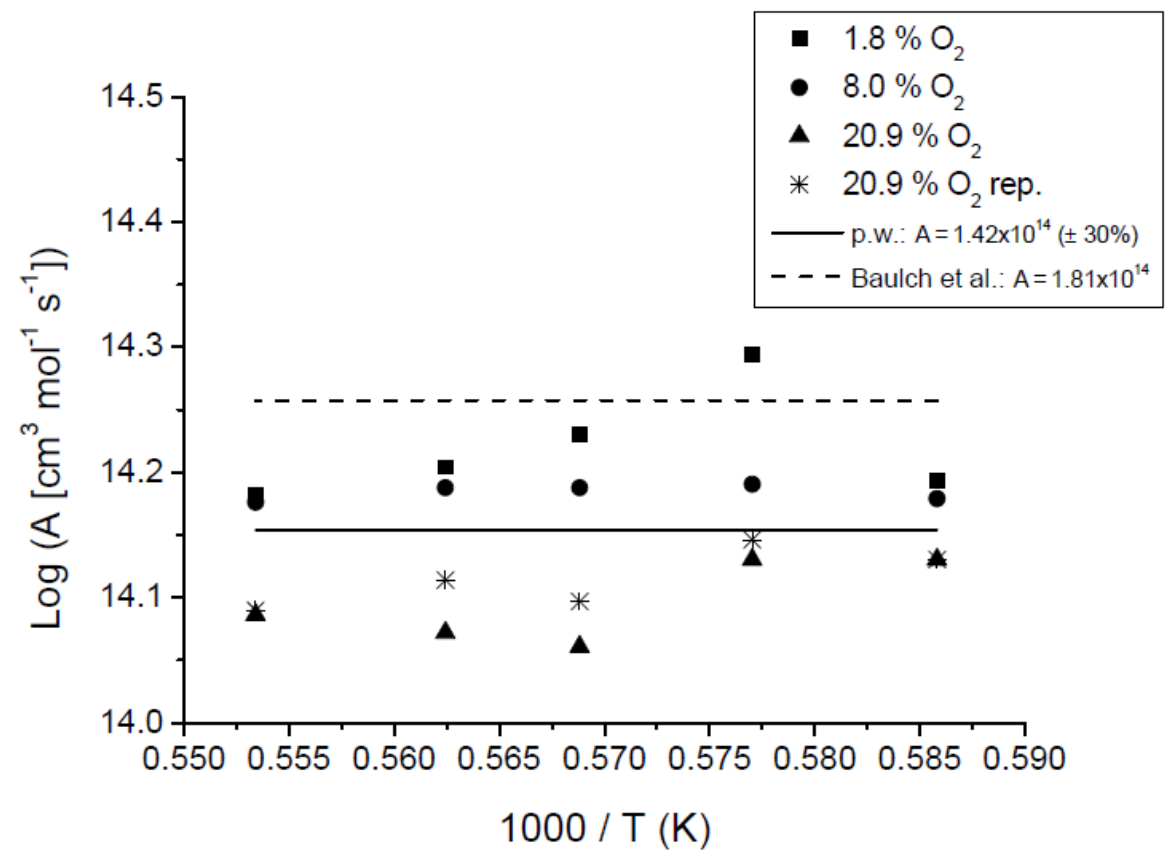

Figure 2: Arrhenius plot for the derived pre-exponential factor $\mathrm{A}$ for the $\mathrm{O}+$ $\mathrm{N}_{2}$ reaction (R1), derived from experiments with $\mathrm{O}_{2} / \mathrm{N}_{2}$ mixtures with $1.8 \%$, $8.0 \%, 20.9 \% \mathrm{O}_{2}$ in $\mathrm{N}_{2}$. The experimental data used for the fitting procedure correspond to sets $2-4$ in Table 1. 


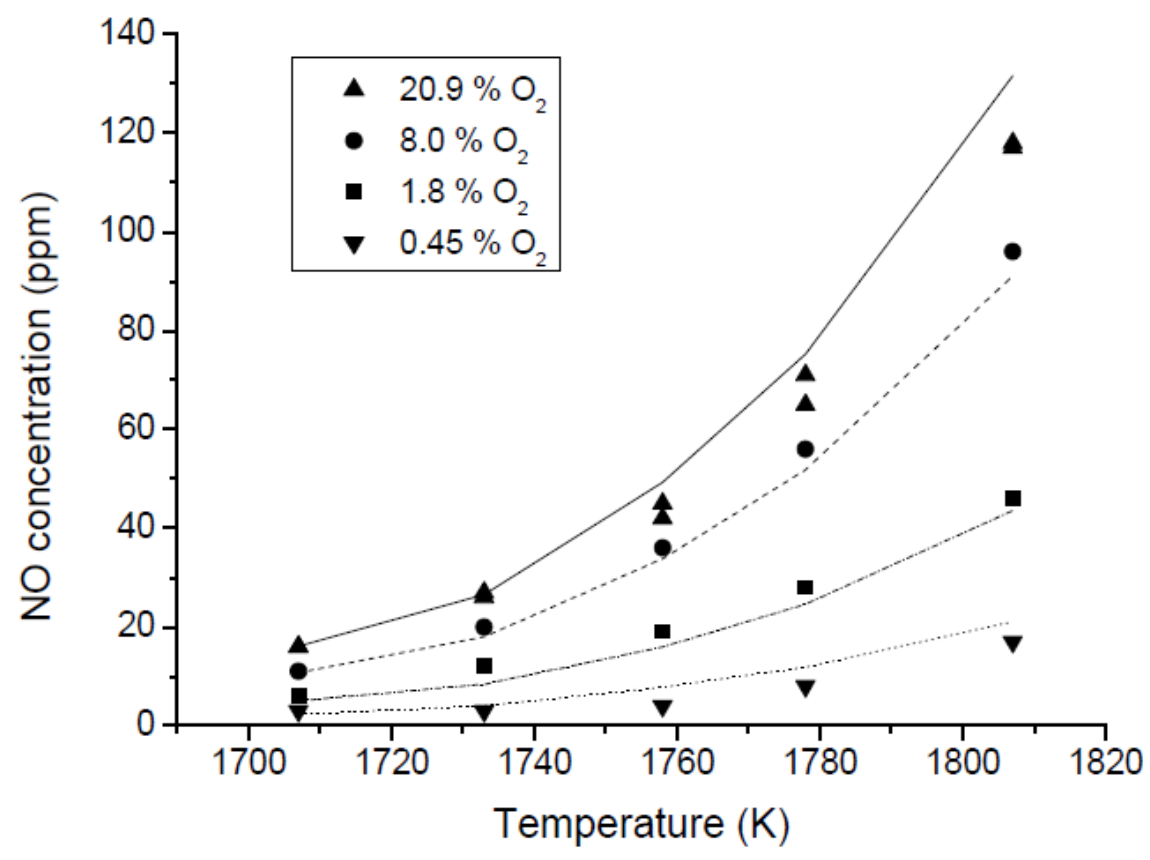

Figure 3: Comparison of experimental and predicted NO concentration results from $0.45 \% \mathrm{O}_{2}, 1.8 \% \mathrm{O}_{2}, 8.0 \% \mathrm{O}_{2}$, and $20.9 \% \mathrm{O}_{2}$ in $\mathrm{N}_{2}$ mixtures over the 1700-1800 K temperature range. The symbols mark experimental results, whereas lines denote model predictions using the determined $\mathrm{k}_{1}$ value. 


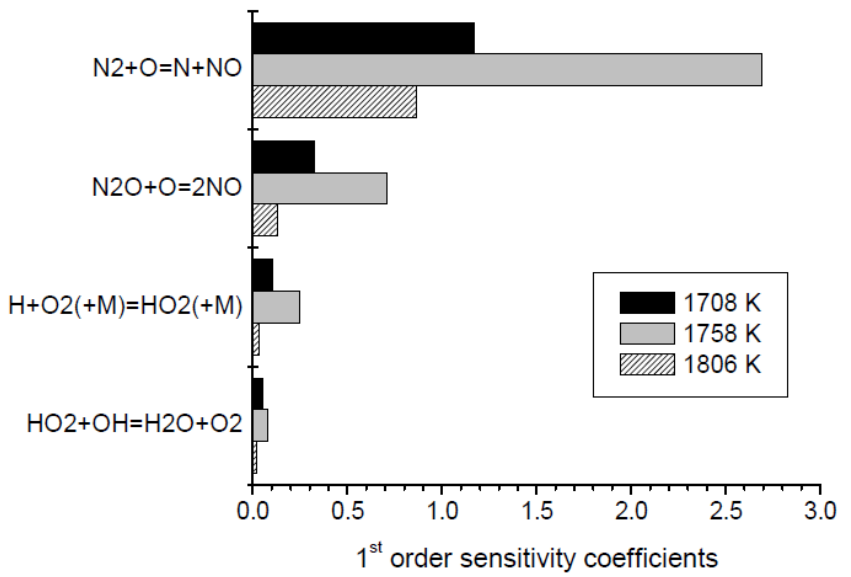

Figure 4: Normalized first-order sensitivity coefficients calculated for NO formation from $20.9 \% \mathrm{O}_{2}$ in $\mathrm{N}_{2}$ mixture at 1708,1758 and $1807 \mathrm{~K}$, respectively. 


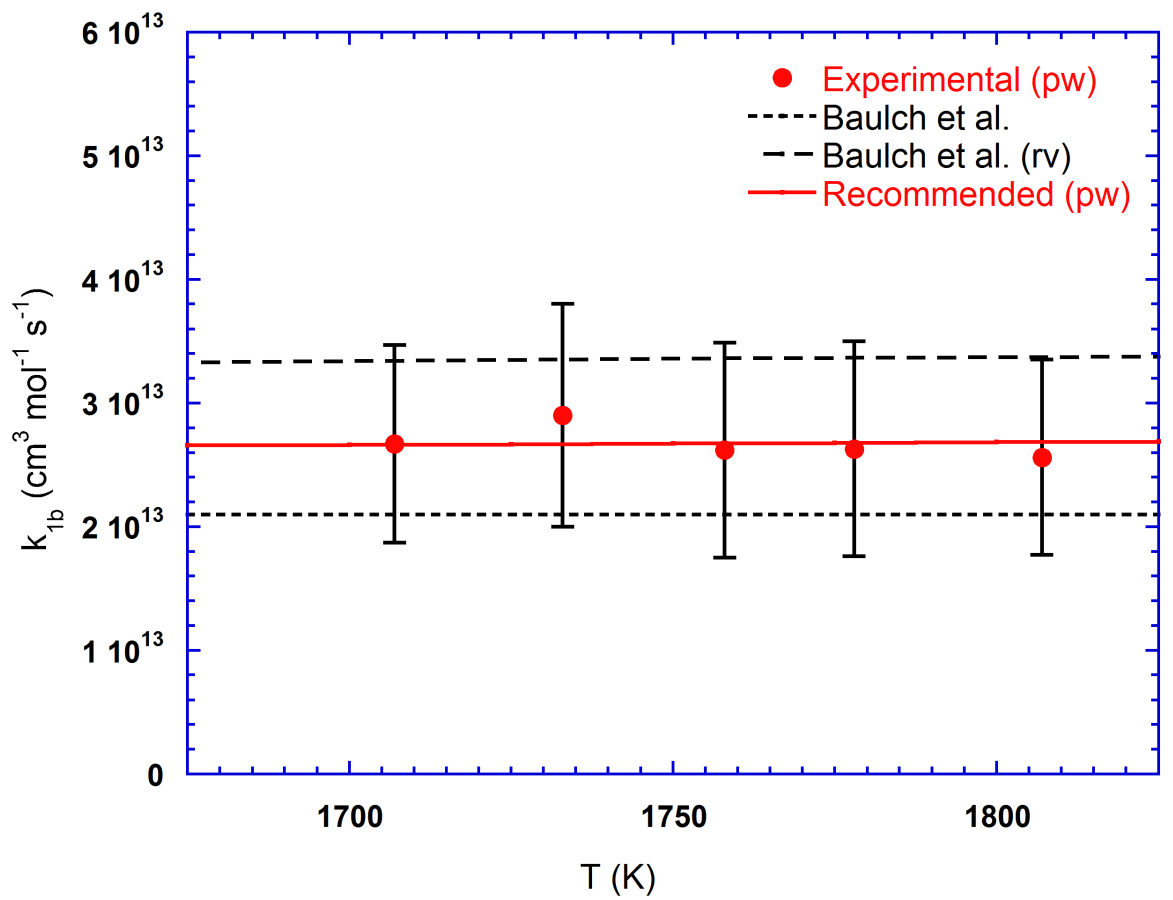

Figure 5: Comparison of the present data for $\mathrm{k}_{1 \mathrm{~b}}$ with the recommendations from Baulch et al. [35] and with the recommended rate constant. The symbols denote measurements of the present work. The long-dashed line shows the recommendations of Baulch et al. [35] for $\mathrm{k}_{1 \mathrm{~b}}$, while the short-dashed line is the value of $k_{1 b}$ derived from their recommendation of $k_{1}$ through the equilibrium constant. The solid line is the rate constant recommended in the present work, $\mathrm{k}_{1 \mathrm{~b}}=9.4 \times 10^{12} \mathrm{~T}^{0.14} \mathrm{~cm}^{3} \mathrm{~mol}^{-1} \mathrm{~s}^{-1}$. 


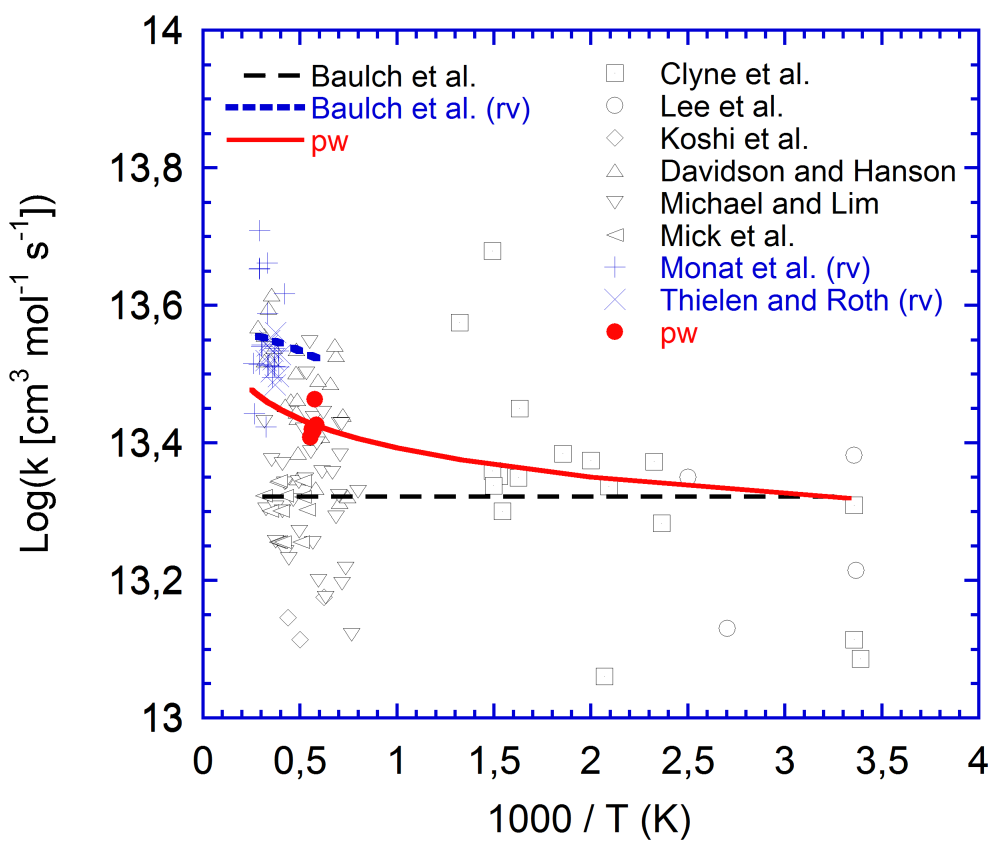

Figure 6: Arrhenius plot for the reaction $\mathrm{N}+\mathrm{NO} \rightleftharpoons \mathrm{O}+\mathrm{N}_{2}$ (R1b). The black symbols denote measurements of the forward reaction while the blue symbols denote data obtained from measurements of the reverse step, converted using the thermodynamic properties of the present work. Data for (R1b): Clyne et al. [17,21,23,26], Lee et al. [22], Koshi et al. [29], Davidson and Hanson [28], Michael and Lim [31], Mick et al. [32]; "pw" is the present work. Data derived from measurements of $\mathrm{k}_{1 \mathrm{~b}}$ : Monat et al. [6] and Thielen and Roth [7]. The long-dashed line shows the recommendations of Baulch et al. [35] for $\mathrm{k}_{1}$, while the short-dashed line is the value of $\mathrm{k}_{1}$ derived from their recommendation of $\mathrm{k}_{1 \mathrm{~b}}$. The solid line is the rate constant recommended in the present work, $\mathrm{k}_{1 \mathrm{~b}}=9.4 \times 10^{12} \mathrm{~T}^{0.14} \mathrm{~cm}^{3} \mathrm{~mol}^{-1} \mathrm{~s}^{-1}$. 


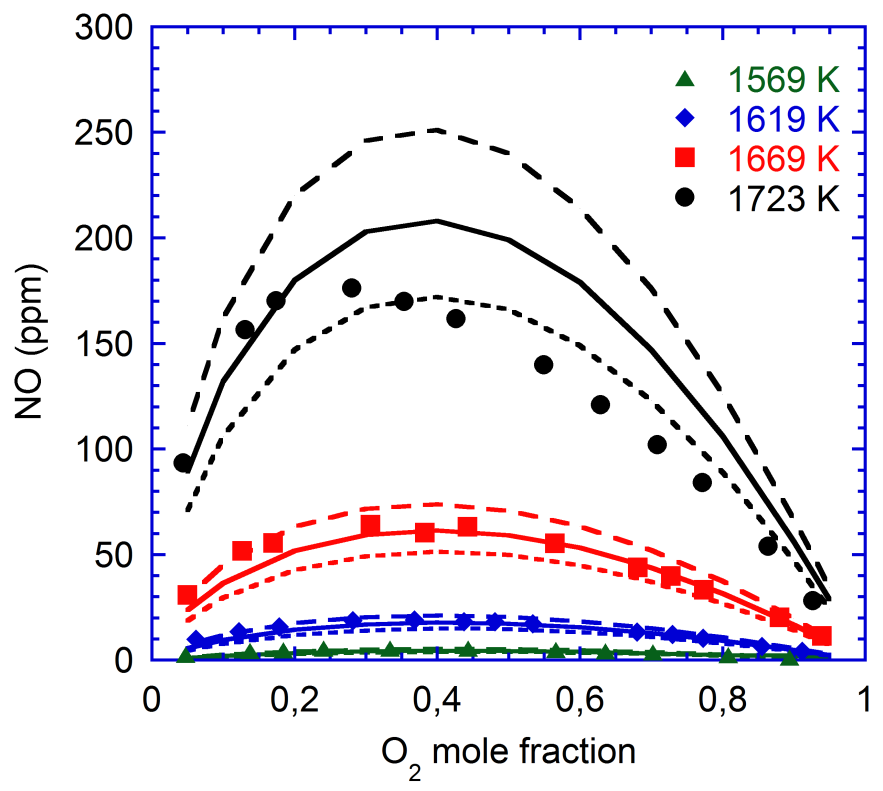

Figure 7: Formation of NO from $\mathrm{N}_{2}$ and $\mathrm{O}_{2}$ in a flow reactor as a function of temperature and mole fraction of $\mathrm{O}_{2}$ in the $\mathrm{O}_{2} / \mathrm{N}_{2}$ reactant gas mixture. Comparison between experimental data (symbols) from Arai et al. [66] and model predictions. Calculations with the present kinetic model are shown as solid lines while long-dashed lines and short-dashed lines denote predictions with recommended rate constants for (R1) and (R1b), respectively, from Baulch et al. [35]. 


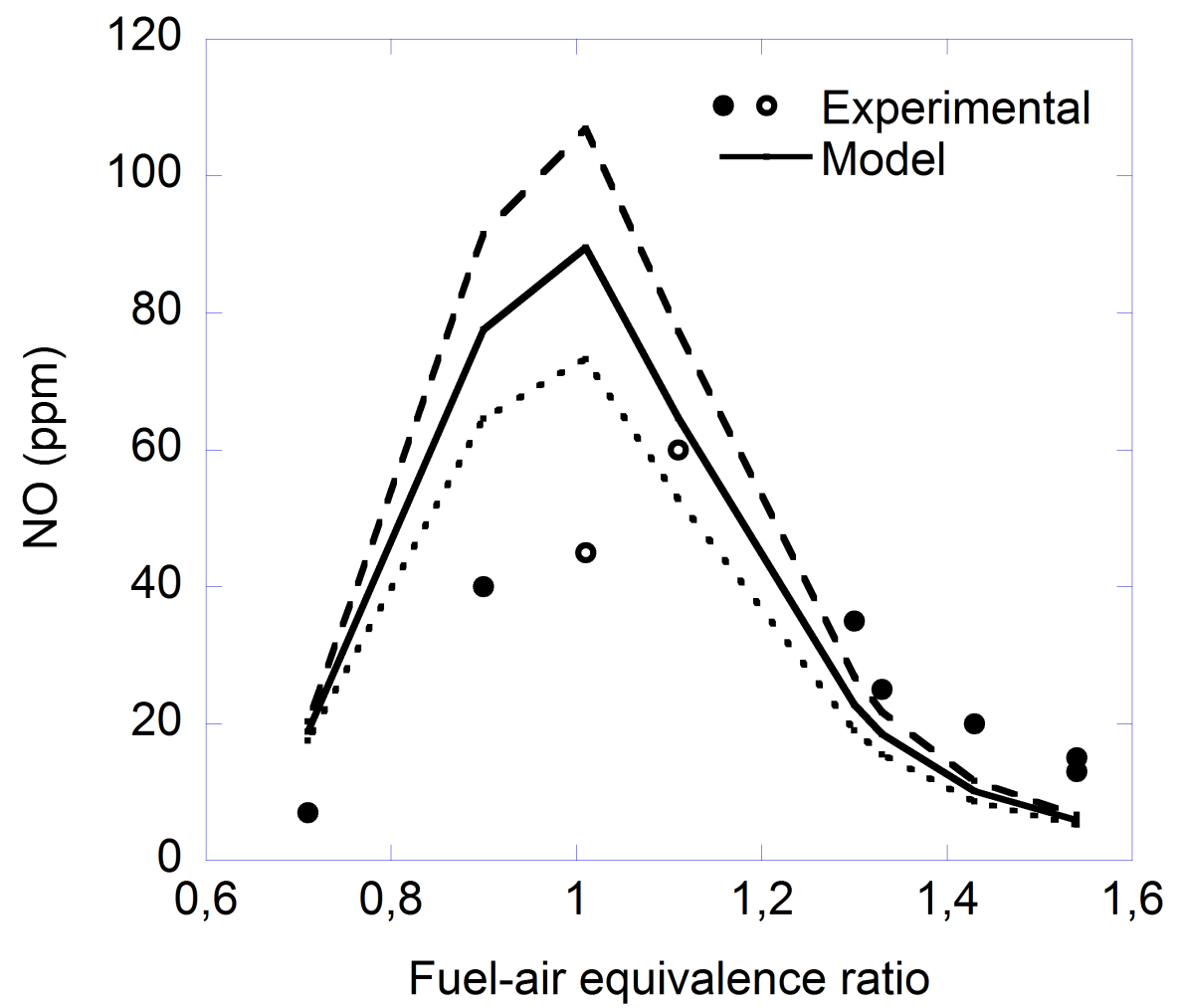

Figure 8: Comparison of measured [68] and predicted mole fractions of NO in hydrogen/air combustion in a jet-stirred reactor. The symbols denote experimental data, while the lines denote calculated values. Calculations with the present kinetic model are shown as solid lines while long-dashed lines and short-dashed lines denote predictions with recommended rate constants for (R1) and (R1b), respectively, from Baulch et al. [35]. Reactor conditions: $\bar{\tau}=3.0 \mathrm{~ms}, \mathrm{~T}_{\mathrm{in}}=464 \mathrm{~K}, \mathrm{P}=1 \mathrm{~atm}$. In the calculations, the measured temperatures are used. 


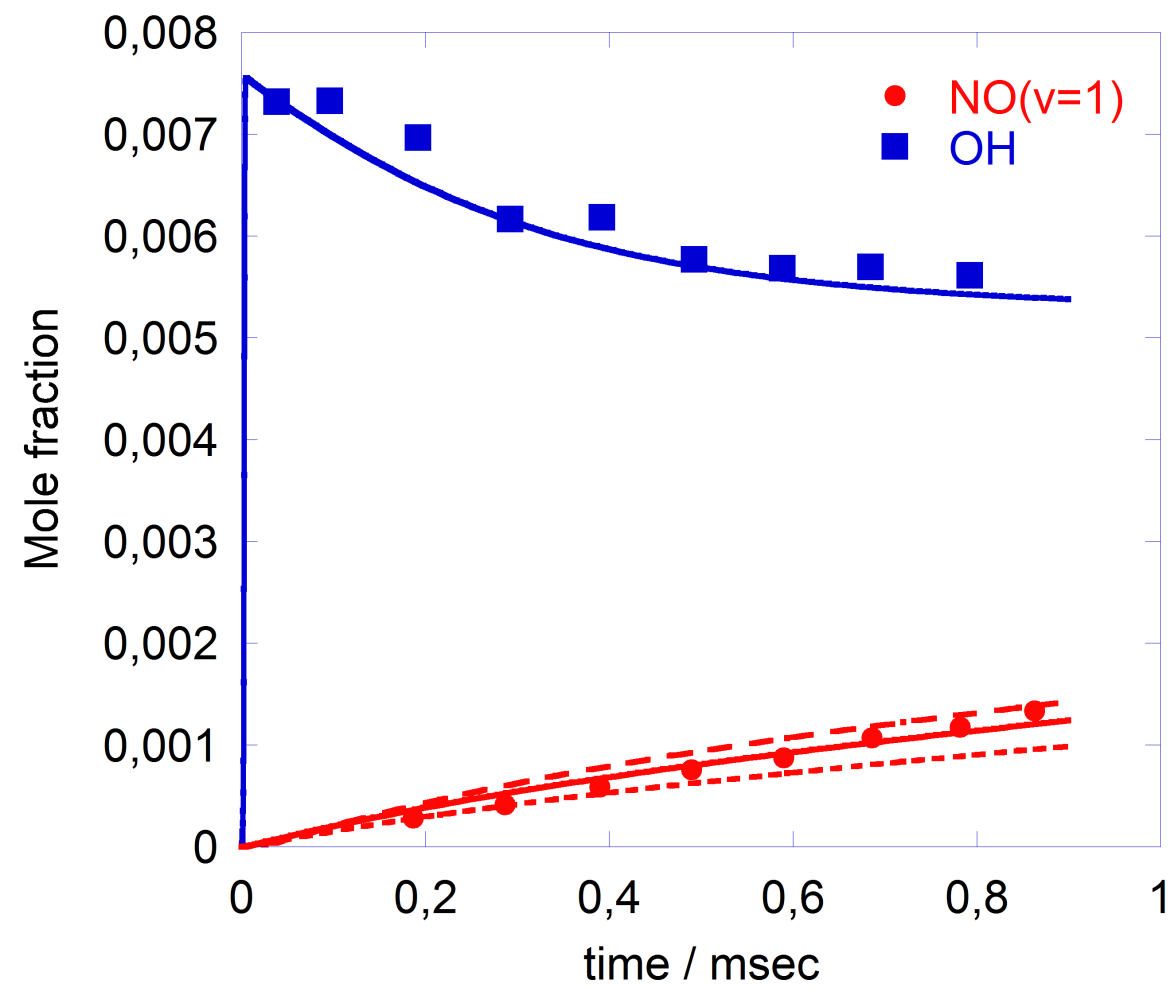

Figure 9: Comparison of measured and predicted mole fractions of $\mathrm{NO}$ and $\mathrm{OH}$ from oxidation of $\mathrm{H}_{2}$ in $\mathrm{O}_{2} / \mathrm{N}_{2}$ in a reflected shock tube experiment. The symbols denote experimental data from Bowman [70], while the lines denote calculated values. Calculations with the present kinetic model are shown as solid lines while long-dashed lines and short-dashed lines denote predictions with recommended rate constants for (R1) and (R1b), respectively, from Baulch et al. [35]. Conditions: $2 \% \mathrm{H}_{2}, 6 \% \mathrm{O}_{2}, 92 \% \mathrm{~N}_{2}$; initial temperature $2560 \pm 20 \mathrm{~K}$; initial pressure $2.07 \pm 0.03 \mathrm{~atm}$. The calculations were conducted assuming adiabatic conditions. 


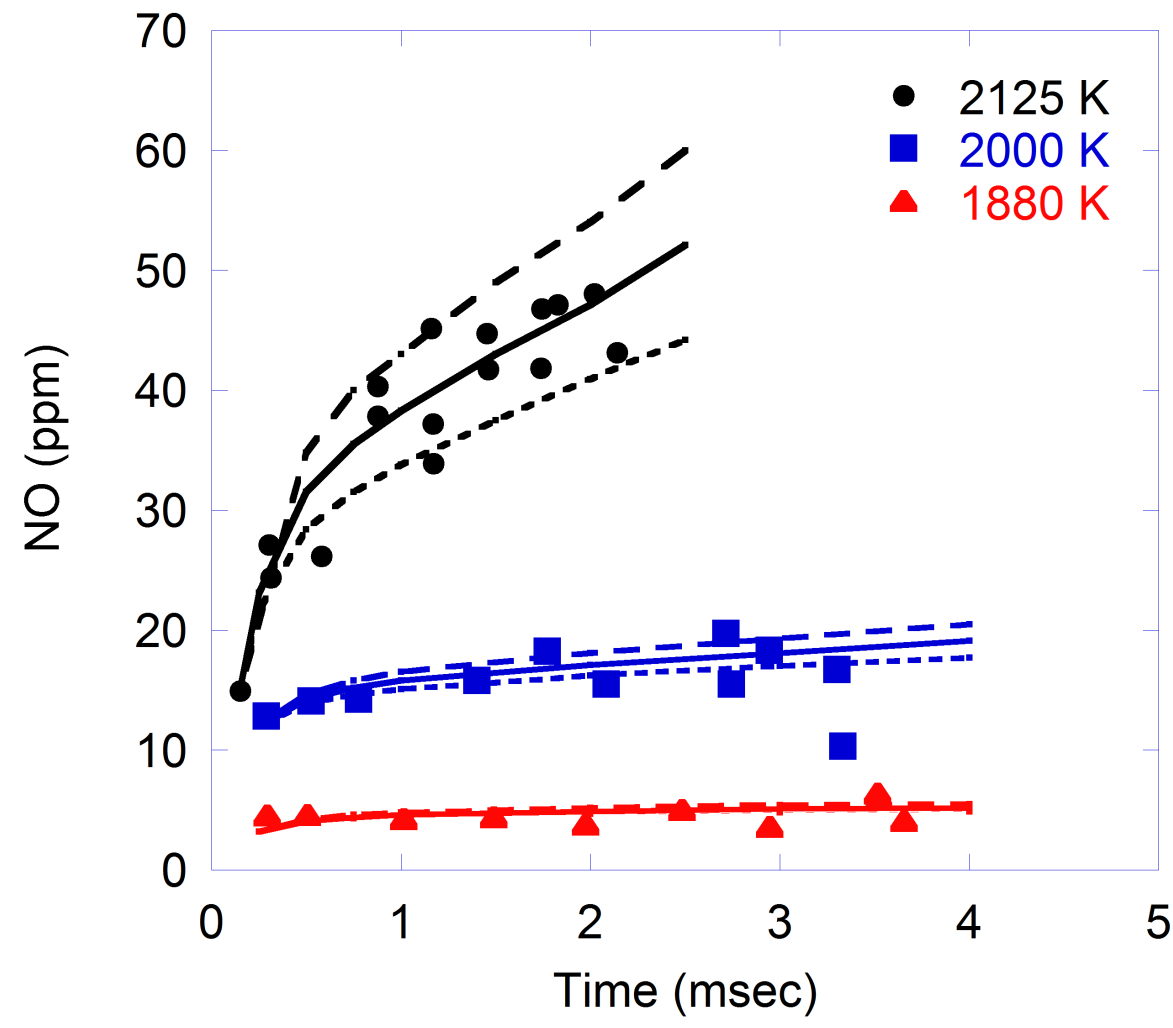

Figure 10: Comparison of measured and predicted mole fractions of NO in the post-flame zone of an atmospheric pressure $\mathrm{H}_{2} / \mathrm{O}_{2} / \mathrm{N}_{2}$ premixed laminar flame. The symbols denote experimental data from Homer and Sutton [72], while the lines denote calculated values. Calculations with the present kinetic model are shown as solid lines while long-dashed lines and short-dashed lines denote predictions with recommended rate constants for (R1) and (R1b), respectively, from Baulch et al. [35]. Flame 1: Temperature $2125 \mathrm{~K}$, inlet composition $25 \% \mathrm{H}_{2}, 17.5 \% \mathrm{O}_{2}, 57.5 \% \mathrm{~N}_{2}$. Flame 2: Temperature $2000 \mathrm{~K}$, inlet composition $23 \% \mathrm{H}_{2}, 16.1 \% \mathrm{O}_{2}, 60.9 \% \mathrm{~N}_{2}$. Flame 3: Temperature 1880 $\mathrm{K}$, inlet composition $21.1 \% \mathrm{H}_{2}, 14.7 \% \mathrm{O}_{2}, 64.2 \% \mathrm{~N}_{2}$. 